\title{
Conversion Efficiency of Photosynthetically Active Radiation Into Acacia mearnsii Biomass
}

\author{
Elder Eloy ${ }^{1}$, Elvis Felipe Elli², Felipe Schwerz ${ }^{3}$ \\ ${ }^{1}$ Department of Forest Engineering, Universidade Federal de Santa Maria - UFSM, Frederico Westphalen/RS, Brazil \\ ${ }^{2}$ Department of Biosystems Engineering, "Luiz de Queiroz" College of Agriculture - ESALQ, \\ Universidade de São Paulo - USP, Piracicaba/SP, Brazil \\ ${ }^{3}$ Department of Plant Sciences, "Luiz de Queiroz" College of Agriculture - ESALQ, \\ Universidade de São Paulo - USP, Piracicaba/SP, Brazil
}

\begin{abstract}
The objective of this experiment was to determine the conversion efficiency of intercepted photosynthetically active radiation into biomass of Acacia mearnsii De Wild. seedlings. A forest species, plastic tubes $\left(90 \mathrm{~cm}^{3}\right.$ ), and 11 evaluation periods (up to 180 days after emergence) were used in this study. The leaf area index (LAI), total dry biomass (BIO), global solar radiation (GSR), cumulative intercepted photosynthetically active radiation (PARic), and conversion efficiency of radiation ( $\varepsilon b)$ were determined using a pyranometer (LI200X, LICOR). The value of $\varepsilon b$ in BIO seedlings of Acacia mearnsii was $7.76 \mathrm{~g} \mathrm{MJ}^{-1}$. LAI was directly related to the efficiency of PARic, and this influenced the development, production potential and accumulation of BIO. The value of GSR flow was $11.81 \mathrm{MJ} \mathrm{m}^{-2} \mathrm{day}^{-1}$, while the value inside the greenhouse was $6.26 \mathrm{MJ} \mathrm{m}^{-2} \mathrm{day}^{-1}$.
\end{abstract}

Keywords: black wattle, global solar radiation, leaf area index. 


\section{INTRODUCTION}

The success of forestry plantations depends on numerous factors, such as quality of the seedlings produced, seedling productivity and the techniques used (Beadle et al., 2013). Thus, it is necessary to determine suitable production methods for seedlings to have high survival rates and excellent performance in the field.

Seedlings produced in plastic greenhouses have been used for the propagation of forest plantations, especially of the genus Acacia. However, cultivation in protected environments causes changes in weather elements, such as solar radiation. Within the greenhouse, this element is one of the first to be modified (Caron et al., 2012), and is therefore considered a determinant factor in the growth and development of seedlings.

Solar radiation is an essential energy source for the maintenance of any cultivated species whose interactions with vegetation cover creates a microclimate capable of affecting the quantity and quality of energy available within the canopy, and consequently, the physiological processes of plants (Albaugh et al., 2014; Ehrenbergerová et al., 2016; Hung et al., 2016). Solar radiation, when intercepted by a crop, plays a fundamental role in the environment, and the available energy balance is associated with biomass production (Monteith \& Moss, 1977). The amount of radiation available for plants is a function of several factors, including physiological and morphological characteristics, such as growth pattern, leaf angle and leaf position (Netto et al., 2015).

Plant growth depends on the dry matter accumulated by photosynthesis (Taiz \& Zeiger, 2013). Thus, the amount of photosynthetically active radiation (PARi) intercepted by the canopy and the efficiency of the plant at converting this energy into dry matter, which is linked to its nutritional status, determines the accumulation of biomass by healthy plants that have received adequate water and nutrients (Monteith \& Moss, 1977). Thus, the conversion of PARi into biomass indicates the efficiency of the use of radiation by the species.

This mechanism has been demonstrated as a linear function (Campoe et al., 2013), wherein the angular curve between PARi and the accumulated dry matter determines the efficiency of the use of radiation for biomass production (Caron et al., 2003; Radin et al., 2003; Raes et al., 2009).
The association proposed by Monteith between biomass yield and the amount of PAR is one of the most simplified models to estimate plant growth and yield, and is the basis for ecophysiological models that take into account PARi on leaves (Landsberg \& Waring, 1997). This is very important for studies related to forest ecophysiology (Binkley et al., 2004) and has many applications.

The absorption of incident radiation by crops depends on their leaf area index (Behling et al., 2015a), solar angle or solar zenith angle, geometry, size, leaf angle and leaf distribution, age, plant arrangement, time of year, cloud cover (Varlet-Grancher et al., 1989), meteorological conditions and crop management practices (Quentin et al., 2011; Caron et al., 2012). The efficiency of radiation use may vary, depending on how the dry matter (air or total) and solar radiation (incident, intercepted, and absorbed) are defined and determined (Gallo et al., 1993).

Thus, quantitative approximation can be used to determine the relationship between biomass production and intercepted radiation. This information can be useful for plant growth analysis, growth and development forecasting and estimation of production potential (Caron et al., 2012, 2014).

The conversion of photosynthetically active radiation into biomass varies between species of economic interest. In order to identify production potential and the factors limiting productivity, it is necessary to determine the conversion efficiency for each crop in different production systems. Thus, this study aimed to determine the efficiency of conversion of PARi in biomass of Acacia mearnsii De Wild. seedlings.

\section{MATERIAL AND METHODS}

The experiment was conducted in a greenhouse with geographic coordinates of $27^{\circ} 23^{\prime} \mathrm{S} 53^{\circ} 25^{\prime} \mathrm{W}$ at $461 \mathrm{~m}$ altitude. According to Köppen climatic classification system, the climate was classified as Cfa (mean air temperature of the three coldest months was between $-3^{\circ} \mathrm{C}$ and $18^{\circ} \mathrm{C}$, with precipitation occurring during all months of the year, and average air temperature in the warmer months equal to or above $22^{\circ} \mathrm{C}$ ). The municipality of Frederico Westphalen is located $30 \mathrm{~km}$ from Iraí, in the state of Rio Grande do Sul. The latter was taken as a reference for climate classification data. As proposed 
by Maluf (2000), Iraí has a sub-humid sub-temperate climate, with an annual average temperature of $18.8^{\circ} \mathrm{C}$.

A randomized complete block design was used for treatments. A forest species (Acacia mearnsii De Wild.), one container size and 11 post-emergence evaluation periods were evaluated; five replications were performed. The experimental units consisted of five plants in each evaluation period, using double border, 25 plants per period. A total of 275 plants were evaluated within all evaluated periods.

Seeds harvested during the previous year were used; these had been stored for three months in a refrigerated chamber. Sowing was carried out on 03/15/2010 in conical, open-bottomed polypropylene tubes, with a volume of $90 \mathrm{~cm}^{3}$ packed in plastic trays that contained 96 tubes arranged $1.0 \mathrm{~m}$ above ground level. These were filled with commercial substrate $\left(\right.$ Tecnomax $^{\circledR}$ ) and slow release fertilizer (Basacote ${ }^{\circledR}$ ) at a concentration of 10 grams per liter of substrate, with an average of six seeds per tube container.

Once the seedlings were 10 days old, surplus seedlings were removed from each container, and only one high-quality seedling was left at the center of the container. To maintain the moisture content throughout the experiment, three irrigations (13 min each) were conducted daily in the greenhouse with sprinklers.

Fortnightly evaluations were conducted. The first evaluation was conducted at 30 days after emergence (DAE) and the last one at 180 DAE. The total dry matter of the plants was determined from the sum of the components: leaf, stem, and root (Benincasa, 2003). Each component was packed in labeled paper bags and placed in a forced air circulation oven at $60^{\circ} \mathrm{C}$ until a constant mass was achieved (Silva et al., 2007; Resende et al., 2011). Subsequently, the material was weighed on a precision scale to obtain the mass of the dry matter.

The determination of dry biomass production was based on the model proposed by Monteith \& Moss (1977); in this model, this is a variable dependent on the amount of intercepted photosynthetically active radiation and is multiplied by the conversion efficiency of radiation into dry biomass. Thus, the conversion efficiency of radiation can be calculated by the following equation using the average dry biomass production and intercepted photosynthetically active radiation involved in biomass production $B I O=\varepsilon b \times P A R i: \mathrm{BIO}=$ dry biomass production $\left(\mathrm{g} \mathrm{m}^{-2}\right) ; \varepsilon b=$ conversion efficiency of PARi in dried biomass produced $\left(\mathrm{g} \mathrm{MJ}^{-1}\right) ; \mathrm{PARi}=$ intercepted photosynthetically active solar radiation $\left(\mathrm{MJ} \mathrm{m}^{-2}\right)$.

The value of radiation conversion efficiency is indicated by the angular coefficient, which represents the amount of accumulated biomass for each intercepted energy unit.

PARi was determined based on the model proposed by Varlet-Grancher et al. (1989) as follows PARi $=0.95 \times($ PARinc $) \times(1-e(-K \times L A I)):$ PARi $=$ intercepted photosynthetically active radiation $\left(\mathrm{MJ} \mathrm{m}^{-2}\right)$; PARinc $=$ incident photosynthetically active radiation $\left(\mathrm{MJ} \mathrm{m}^{-2}\right) ; \mathrm{K}=$ extinction coefficient that depends on the optical properties of the leaves and the geometry of the plant canopy (0.8; dimensionless); LAI = leaf area index (dimensionless).

The leaf area was determined using a leaf area integrator (model LI-3000C). The leaf area index was determined from the total leaf area of each plant and the tray area using the following equation $L A I=L A / T A U$ : LAI = leaf area index; $\mathrm{LA}=$ total leaf area of the plant $\left(\mathrm{m}^{2}\right) ; \mathrm{TAU}=$ tray area utilized by the plant $\left(\mathrm{m}^{2}\right)$.

The tray area utilized by the plant corresponds to the useful space occupied, which is defined by the spacing between the plants in the tray.

The overall solar radiation inside the greenhouse was estimated based on the transmissivity of the plastic covering of $53 \%$ of the global solar radiation incident on the greenhouse cover, which was measured at the beginning of the experiment using a pyranometer (LI200X, LICOR). The values of incident global solar radiation were obtained at the Meteorological Station of the National Institute of Meteorology (INMET), which was located approximately $100 \mathrm{~m}$ from the experiment site. The global solar radiation inside the greenhouse was calculated based on the following equation $G S R i=0.53 \times G S R c:$ GSRi $=$ global solar radiation inside the greenhouse $\left(\mathrm{MJ} \mathrm{m}^{-2}\right)$; GSRc $=$ global solar radiation incident on the greenhouse cover $\left(\mathrm{MJ} \mathrm{m}^{-2}\right)$.

The incident photosynthetically active radiation was estimated to be $45 \%$ of the incident global solar radiation. This fraction is similar to the average value obtained by Rio Grande do Sul by Assis \& Mendez (1989) and Pandolfo (1995). The estimation of the accumulated photosynthetically active radiation was based on 
Monteith \& Moss (1977) and Varlet-Grancher et al. (1989)

The data were analyzed by conducting analysis of variance, F-test, Bartlett's test of homogeneity of variances, normality of the distribution of residues of analysis of variance and regression analysis using the Statistical Analysis System (SAS Institute, 2003).

\section{RESULTS AND DISCUSSION}

The values of global solar radiation flow were within a range of 1.71 to $25.12 \mathrm{MJ} \mathrm{m}^{-2}$ day $^{-1}$ with an average value of $11.81 \mathrm{MJ} \mathrm{m}^{-2} \mathrm{day}^{-1}$, while the values inside the greenhouse were within a range of 0.91 to $13.31 \mathrm{MJ} \mathrm{m}^{-2}$ day $^{-1}$ with an average value of $6.26 \mathrm{MJ} \mathrm{m}^{-2}$ day $^{-1}$.

There was a positive linear relationship between increase in dry biomass and accumulated intercepted photosynthetically active radiation, with a high value for coefficient of determination. The same was observed for radiation conversion efficiency, leaf area, and leaf area index (Figure 1). This trend was demonstrated as a linear function and has been previously observed in other forest species (Stape et al., 2008; Caron et al., 2012, 2014; Campoe et al., 2013).
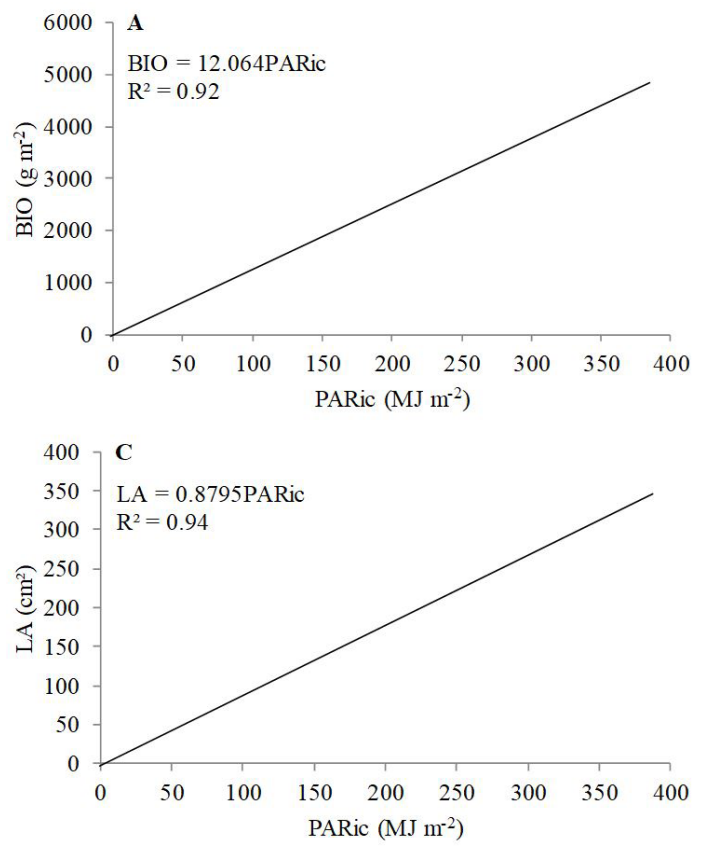

The efficiency of the interception of the photosynthetically active radiation is directly related to the leaf area index (Figure 1), and an increase in this parameter leads to an increase in radiation interception (Caron et al., 2014). Thus, this factor directly influences the development, leaf area and biomass production potential (Mayers et al., 1991).

The efficiency of solar energy utilization by the seedlings is indicated by the value of the angular coefficient. The values obtained during this experiment indicated that the higher the leaf area index, the greater the efficiency of radiation use. The values for conversion efficiency of intercepted photosynthetically active radiation in total dry matter of Acacia mearnsii seedlings were within the range of $5.45 \mathrm{~g} \mathrm{MJ}^{-1}$ to $13.76 \mathrm{~g} \mathrm{MJ}^{-1}$ and the average was $7.76 \mathrm{~g} \mathrm{MJ}^{-1}$ (Figure 1B). This conversion efficiency accounted for $93 \%$ of the total dry matter production; the standard error of the estimate was less than $14 \%$ and the value of standard error was low (0.21).

Analysis of variance indicated that there were significant differences in all the analyzed variables. The values of the coefficients of determination obtained for the regression equations were high; these were 0.98 for leaf area, leaf area index, radiation conversion efficiency, and total dry biomass, and 0.99
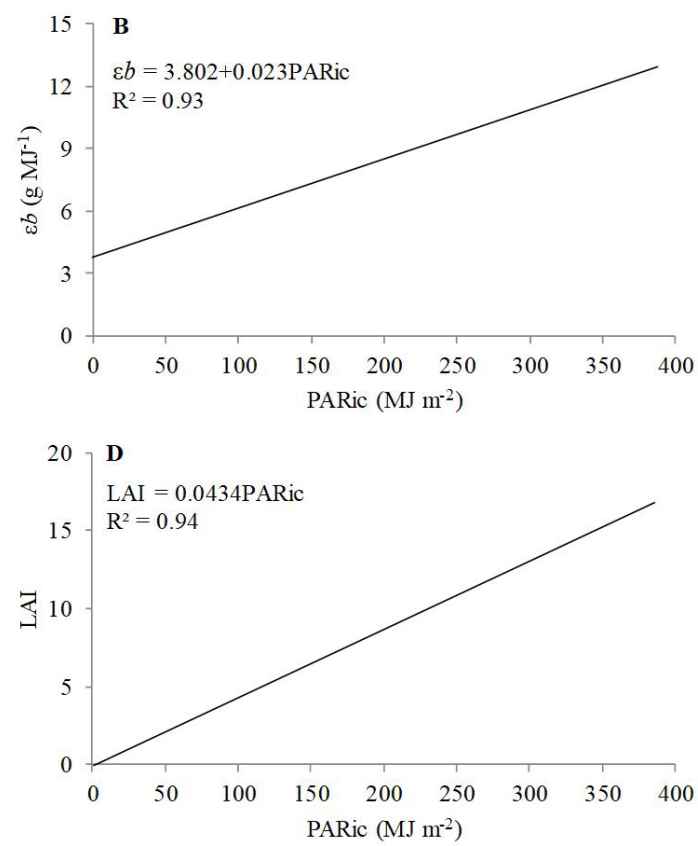

Figure 1. Relationship between cumulative intercepted photosynthetically active radiation (PARic) and the production of total dry biomass (BIO) (A), radiation conversion efficiency ( $(\mathrm{b})(\mathrm{B})$, leaf area (LA) (C), and leaf area index (LAI) (D) in seedlings of Acacia mearnsii. 
for accumulated intercepted photosynthetically active radiation (Figure 2).

Because of the transmissivity of the plastic, the amount of global solar radiation incident on the greenhouse environment was low. However, this decrease can be partially compensated by an increase in the diffuse radiation fraction, which is important because it is multidirectional and has better penetration into the vegetative canopy (Buriol et al., 1995). As a consequence, the values for radiation use efficiency are higher for crops inside plastic greenhouses compared to the external environment (Hammer \& Vanderlip, 1989; Caron et al., 2012). Farias et al. (1993) observed that the diffuse radiation in the external environment was on an average $65 \%$ less compared to the interior of the greenhouse.
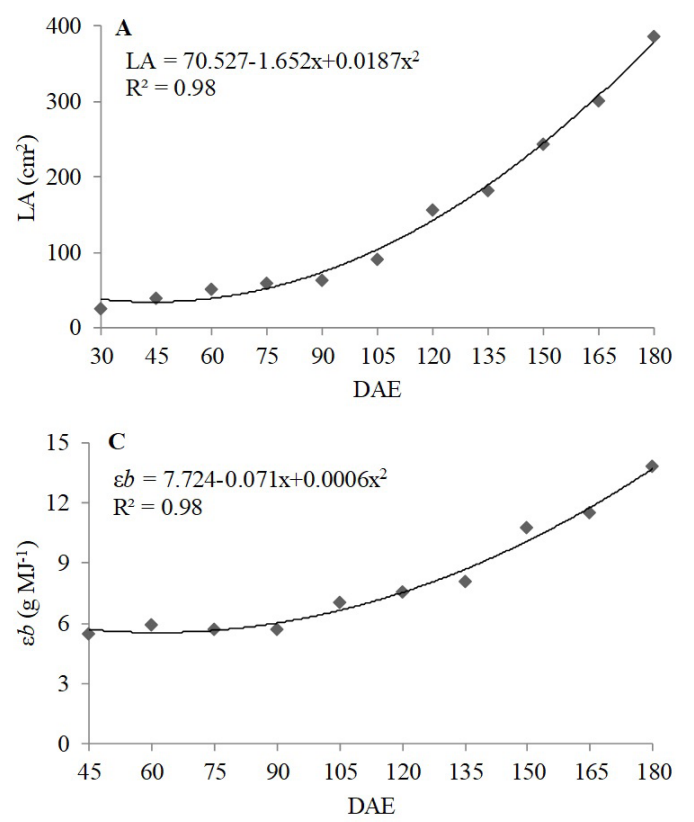

An increase in diffuse radiation promotes greater uniformity of radiation inside the canopy, leading to an increase in the interception and use of radiation by lower leaves (Caron et al., 2012). In addition, leaves subjected to high solar radiation intensities can lead to light saturation and reduction in radiation use efficiency (Jiang et al., 2004). Higher radiation use efficiency can also be explained by an increase in the relative contribution of shaded leaves to biomass accumulation in Acacia mearnsii seedlings. A similar observation was made for tomato plants by Radin et al. (2003).

The accumulation of dry matter is closely related to the index of leaf area, because an increase in index of leaf area leads to an increase in the amount of intercepted photosynthetically active radiation consequently resulting in biomass accumulation (Stewart et al., 2003).
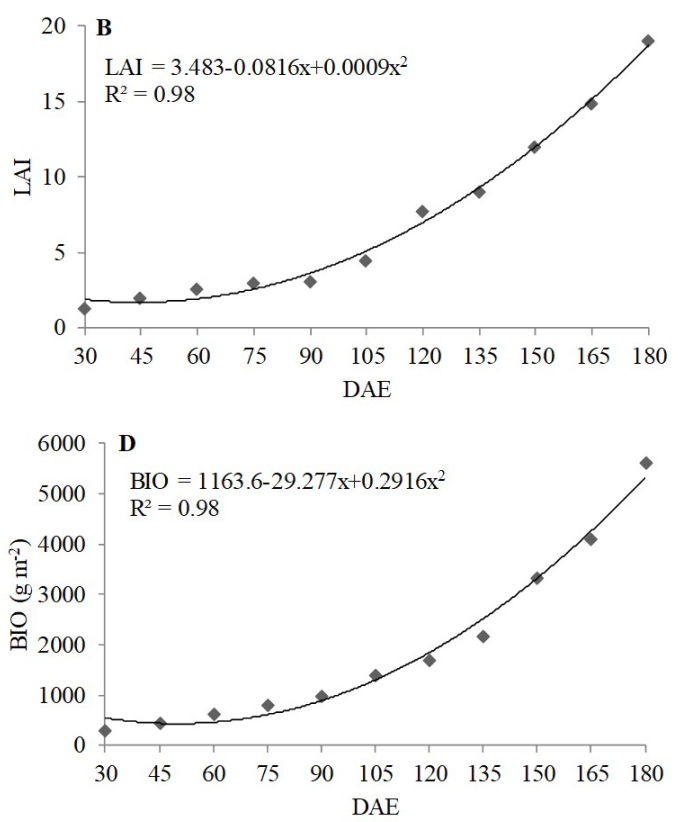

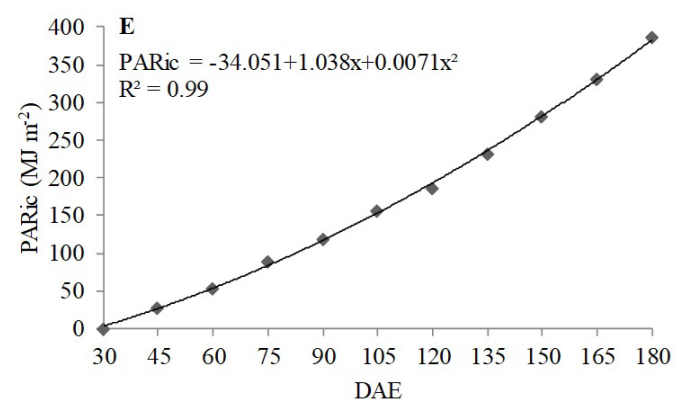

Figure 2. Regression equations for days after emergence (DAE) in relation to leaf area (LA) (A), leaf area index (LAI) (B), radiation conversion efficiency $(\varepsilon b)(C)$, total dry biomass (BIO) (D), and intercepted accumulated photosynthetically active radiation (PARic) (E) in Acacia mearnsii seedlings. 
These observations indicate that plant arrangement is an important management practice because the interaction with the interception of solar radiation is one of the main determinants of the growth and development of a culture. The effect of light on seedling growth has been observed by de Silva et al. (2007), Dantas et al. (2009), Resende et al. (2011), and Caron et al. (2012).

Along with the rapid closure of the vegetative canopy of the seedlings in the tray, there was an increase in radiation as well as better utilization. This led to greater uniformity of radiation inside the canopy, causing the lower leaves to increase the interception and use of radiation. These results are in agreement with those obtained by Sanquetta et al. (2014) when working with Eucalyptus dunnii seedlings. There, they observed better radiation use efficiency in plants that were more densely packed in the tray, indicated by the increase in the relative contribution of the shaded leaves to biomass accumulation. Moreover, Caron et al. (2012) observed that an increase in seedling density of Eucalyptus grandis increased radiation use efficiency by $44 \%$.

The values obtained for conversion efficiency of photosynthetically active radiation into biomass of Acacia mearnsii seedlings were higher than those observed in greenhouse cultures of tomato $\left(2.5 \mathrm{~g} \mathrm{MJ}^{-1}\right)$ by Heuvelink (1995), of melon (2.21 $\left.\mathrm{g} \mathrm{MJ}^{-1}\right)$ by Caron et al. (2002), and of lettuce (1.28 $\mathrm{g} \mathrm{MJ}^{-1}$ in the summer crop and $1.8 \mathrm{~g} \mathrm{MJ}^{-1}$ in the spring crop) by Caron et al. (2003, 2012) obtained a value of $6.88 \mathrm{~g} \mathrm{MJ}^{-1}$ in the production of Eucalyptus grandis seedlings, and Sanquetta et al. (2014) obtained a value of $7.75 \mathrm{~g} \mathrm{MJ}^{-1}$ in the production of Eucalyptus dunnii seedlings. Depending on the pea genotype, the values for non-greenhouse crops ranged between 1.52 and 2.99 $\mathrm{MJ} \mathrm{m}^{-2}$ (Lecoeur \& Ney, 2003).

The highest conversion efficiency values observed in the evaluated periods were related to the faster occupation of the space between the seedlings by leaf area, which can be verified by the high values for leaf area index obtained during these periods (Figure 2). The surface area for radiation absorption as well as the accumulation of photosynthetically active radiation increased along with an increase in leaf area index; consequently, the biomass production was also higher (Figure 1).

Water and nutrients are not limiting factors in seedling cultivation because these elements can be controlled by the forester (Sanquetta et al., 2014). Based on their observations, Caron et al. (2012) proposed that biomass production is controlled by solar radiation. Thus, the growth of Acacia mearnsii seedlings depends on the amount of intercepted photosynthetically active radiation and the efficiency of the use of this energy in the photosynthetic process for biomass production.

Sinclair \& Muchow (1999) suggest that conversion efficiency is the result of several intrinsic and extrinsic factors, including species, photosynthetic process, gas exchange, nutrient concentration in the leaves, soil resources, atmospheric pressure deficit steam, air temperature and solar radiation. Research conducted by Close et al. (2004) and Stape et al. (2008) demonstrated that photosynthetic capacity is directly related to the concentration of nitrogen in the leaves.

Acacia mearnsii is associated with bacteria belonging to the genus Rhizobium that fixes atmospheric nitrogen in the substrate. Therefore, this element is not likely to be a limiting growth factor (Behling et al., 2015b). Leguminosae accumulate nitrogen in their biomass more easily, consequently, they have higher conversion efficiency, which affects photosynthesis and productivity rates (Green et al., 2003; Dewar, 2003).

The modeling of the efficiency in the use of incident solar radiation in the seedling accumulation is shown to be consistent in potential models and appropriate for the analysis of seedling growth (Müller \& Bergamaschi, 2005). However, technical criteria, such as the space available in the nursery, cost of tube container (Gomes et al., 2003), substrates and seedling management, should also be taken into account for the production of seedlings that would be suitable for planting.

The values obtained for the coefficients of determination were high. Hence, the planning of the production of Acacia mearnsii seedlings can be reliably carried out. In order to this, it is necessary to have information regarding the transmissivity of the greenhouse plastic (which can be obtained from the manufacturer) and the global solar radiation values, which can be obtained from nearby meteorological stations or from solar radiation charts.

The results of radiation use efficiency obtained from this study can be applied to several research topics (Manzanares et al., 1993), such as the analysis of plant 
growth, prediction of cultivation time, competition between plants, and estimation of production potential.

This study highlights a new field of forestry research. It presents a reliable model to estimate the production potential of Acacia mearnsii seedlings and highlights the importance of understanding the conversion efficiency of radiation.

\section{CONCLUSIONS}

The conversion efficiency of accumulated intercepted photosynthetically active radiation in total dry biomass of Acacia mearnsii seedlings was $7.76 \mathrm{~g} \mathrm{MJ}^{-1}$.

The total global solar radiation flow was $11.81 \mathrm{MJ} \mathrm{m}^{-2} \mathrm{day}^{-1}$ and the value inside the greenhouse was $6.26 \mathrm{MJ} \mathrm{m}^{-2}$ day $^{-1}$.

Leaf area index was directly related to the efficiency of incident photosynthetically active radiation, which directly influences the development and potential of total dry biomass production and accumulation.

\section{SUBMISSION STATUS}

Received: 11 feb., 2016

Accepted: 2 june 2017

\section{CORRESPONDENCE TO}

\section{Elder Eloy}

Departamento de Engenharia Florestal, Universidade Federal de Santa Maria - UFSM, campus de Frederico Westphalen Linha 7 de Setembro, s/n, BR $386 \mathrm{Km} \mathrm{40,}$ CEP 98400-000, Frederico Westphalen, RS, Brazil e-mail: eloyelder@yahoo.com.br

\section{REFERENCES}

Albaugh JM, Albaugh TJ, Heiderman RR, Leggett Z, Stape JL, King JS et al. Evaluating changes in switchgrass physiology, biomass, and light-use efficiency under artificial shade to estimate yields if intercropped with Pinus taeda L. Agroforestry Systems 2014; 88(3): 489-503. http://dx.doi. org/10.1007/s10457-014-9708-3.

Assis FN, Mendez MEG. Relação entre radiação fotossinteticamente ativa e radiação global. Pesquisa Agropecuária Brasileira 1989; 2(7): 797-800.

Beadle C, Maria O, Dung PT, Caroline M, Huong VD, Dat KT et al. Optimising silvicultural management and productivity of high-quality acacia plantations, especially for sawlogs. Canberra, Australia: Australian Centre for International Agricultural Research; 2013. p. 123.

Behling A, Sanquetta CR, Corte APD, Netto SP, Caron BO, Simon AA et al. Analysis of leaf area in black wattle throughout its plantation cycle. African Journal of Agricultural Research 2015a; 10(34): 3382-3386. http:// dx.doi.org/10.5897/AJAR2015.9579.

Behling A, Sanquetta CR, Dalla Corte AP, Caron B, Simon AA, Behling $M$ et al. Conversion efficiency of photosynthetically active radiation intercepted in biomass in stands of black wattle in Brazil. Bosque 2015b; 36(1): 6169. http://dx.doi.org/10.4067/S0717-92002015000100007.

Benincasa MMP. Análise de crescimento de plantas (noções básicas). Jaboticabal: CAVUNESP; 2003.

Binkley D, Stape JL, Ryan MG. Thinking about efficiency of resource use in forests. Forest Ecology and Management 2004; 193(1-2): 5-16. http://dx.doi.org/10.1016/j. foreco.2004.01.019.

Buriol GA, Streck NA, Petry C, Schneider FM. Transmissividade da radiação solar do polietileno de baixa densidade utilizado em estufa. Ciência Rural 1995; 25(1): 1-4. http://dx.doi.org/10.1590/S0103-84781995000100001.

Campoe OC, Stape JL, Nouvellon Y, Laclau JP, Bauerle WL, Binkley $D$ et al. Stem production, light absorption and light use efficiency between dominant and non-dominant trees of Eucalyptus grandis across a productivity gradient in Brazil. Forest Ecology and Management 2013; 288: 14-20. http://dx.doi.org/10.1016/j.foreco.2012.07.035.

Caron BO, Medeiros SPL, Manfron PA, Schmidt D, Pommer SF, Bianchi C. Eficiência de conversão da radiação solar fotossinteticamente ativa interceptada em fitomassa de alface. Revista Brasileira de Agrometeorologia 2003; 11(2): 261-268.

Caron BO, Schmidt D, Manfron PA, Behling A, Eloy E, Busanello C. Eficiência do uso da radiação solar por plantas Ilex paraguariensis A. St. Hil. cultivadas sob sombreamento e a pleno sol. Ciência Florestal 2014; 24(2): 1-9. http:// dx.doi.org/10.5902/1980509814563.

Caron BO, Schmidt D, Medeiros SLP, Heldwein AB, Manfron PA. Eficiência de conversão da radiação solar fotossinteticamente ativa e distribuição de fitomassa produzida no meloeiro cultivado em estufa plástica na primavera. Revista Brasileira de Agrometeorologia 2002; 10(2): 215-219.

Caron BO, Souza VQ, Trevisan R, Behling A, Schmidt $\mathrm{D}$, Bamberg $\mathrm{R}$ et al. Eficiência de conversão da radiação fotossinteticamente ativa interceptada em fitomassa de mudas de eucalipto. Revista Árvore 2012; 36(5): 833-842. http://dx.doi.org/10.1590/S0100-67622012000500005.

Close DC, Battaglia M, Davidson NJ, Beadle CL. Withincanopy of nitrogen and photosynthetic activity of Eucalyptus nitens and Eucalyptus globulus in response to nitrogen 
nutrition. Australian Journal of Botany 2004; 52(1): 133140. http://dx.doi.org/10.1071/BT03027.

Dantas BF, Lopes AP, Silva FFS, Lúcio AA, Batista PF, Pires MMML et al. Taxas de crescimento de mudas de catingueira submetidas a diferentes substratos e sombreamentos. Revista Árvore 2009; 33(3): 413-423. http://dx.doi.org/10.1590/S0100-67622009000300003.

Dewar RC. Information theoretic explanation of maximum entropy production, the fluctuation theorem and selforganized criticality in non-equilibrium stationary states. Journal of Physics. A, Mathematical and General 2003; 36: 631-641. http://dx.doi.org/10.1088/0305-4470/36/3/303.

Ehrenbergerová L, Cienciala E, Kučera A, Guy L, Habrová H. Carbon stock in agroforestry coffee plantations with different shade trees in Villa Rica, Peru. Agroforestry Systems 2016; 90(3): 433-445. http://dx.doi.org/10.1007/ s10457-015-9865-z.

Farias JRB, Bergamaschi H, Martins SR. Efeito da cobertura plástica sobre a radiação solar. Revista Brasileira de Agrometeorologia 1993; 1(1): 31-36.

Gallo KP, Daughtry CST, Wiegand CL. Errors in measuring absorbed and computing crop radiation use efficiency. Agronomy Journal 1993; 85(6): 1222-1228. http://dx.doi. org/10.2134/agronj1993.00021962008500060024x.

Gomes JM, Couto L, Leite HG, Xavier A, Garcia SLR. Crescimento de mudas de Eucalyptus grandis em diferentes tamanhos de tubetes e fertilização N-P-K. Revista Árvore 2003; 27(2): 113-127. http://dx.doi.org/10.1590/S010067622003000200001 .

Green DS, Erickson JE, Kruger EL. Foliar morphology and canopy nitrogen as predictors of light-use efficiency in terrestrial vegetation. Agricultural and Forest Meteorology 2003; 115(3-4): 163-171. http://dx.doi.org/10.1016/S01681923(02)00210-1.

Hammer GL, Vanderlip RL. Genotypeby- environment interaction in grain sorghum - I: effects of temperature on radiation use efficiency. Crop Science 1989; 29(2): 370-376. http://dx.doi.org/10.2135/cropsci1989.001118 3X002900020028x.

Heuvelink E. Growth, development and yield of a tomato crop: periodic destructive measurements in a greenhouse. Scientia Horticulturae 1995; 61(1-2): 77-99. http://dx.doi. org/10.1016/0304-4238(94)00729-Y.

Hung TT, Almeida AC, Eyles A, Mohammed C. Predicting productivity of Acacia hybrid plantations for a range of climates and soils in Vietnam. Forest Ecology and Management 2016; 367: 97-111. http://dx.doi.org/10.1016/j. foreco.2016.02.030.

Jiang ACD, Gao HY, Zou Z, Jiang GM, Li LH. Leaf orientation, photorespiration and xanthophyll cycle protect young soybean leaves against high irradiance in field. Environmental and Experimental Botany 2004; 30(2): 1-10.
Landsberg JJ, Waring RH. A generalized model of forest productivity using simplified concepts of radiation-use efficiency, carbon balance and partitioning. Forest Ecology and Management 1997; 95(3): 209-228. http://dx.doi. org/10.1016/S0378-1127(97)00026-1.

Lecoeur J, Ney B. Change with time in potential radiationuse efficiency in field pea. European Journal of Agronomy 2003; 19(1): 91-105. http://dx.doi.org/10.1016/S11610301(02)00019-9.

Maluf JRT. Nova classificação climática do Estado do Rio Grande do Sul. Revista Brasileira de Agrometeorologia 2000; 8: 141-150

Manzanares M, Tenorio JL, Manzanares P, Ayerbe L. Yield and development of kenaf (Hibiscus cannabinus L.) crop in relation to water and interception radiation. Biomass and Bioenergy 1993; 5(5): 337-345. http://dx.doi. org/10.1016/0961-9534(93)90013-T.

Mayers JD, Lawn RJ, Byth DE. Agronomic studies on soybean (Glycine $\max$ (L.) Merrill) in the dry seasons of the tropics. II. Interaction of sowing date and sowing density. Australian Journal of Agricultural Research 1991; 42(7): 1093-1107. http://dx.doi.org/10.1071/AR9911093.

Monteith JL, Moss CJ. Climate and the efficiency of crop production en Britain. Proceedings of the Royal Society of London 1977; 281(980): 277-294. http://dx.doi.org/10.1098/ rstb.1977.0140.

Müller AG, Bergamaschi H. Eficiências de interceptação, absorção e uso da radiação fotossinteticamente ativa pelo milho (Zea mays L.), em diferentes disponibilidades hídricas e verificação do modelo energético de estimativa da massa seca acumulada. Revista Brasileira de Agrometeorologia 2005; 13(1): 27-33.

Netto SP, Sanquetta CR, Caron BO, Behling A, Simon AA, Corte APD et al. Ground level photosynthetically active radiation dynamics in stands of Acacia mearnsii De Wild. Anais da Academia Brasileira de Ciencias 2015; 87(3): 1833-1845. PMid:26375018. http://dx.doi. org/10.1590/0001-3765201520140080

Pandolfo C. Parâmetros básicos para uso na modelagem do rendimento de matéria seca de alfafa (Medicago sativa L.) [dissertação]. Porto Alegre: Universidade Federal do Rio Grande do Sul; 1995.

Quentin AG, Beadle CL, O'Grady AP, Pinkard EA. Effects of partial defoliation on closed canopy Eucalyptus globulus Labilladière: growth, biomass allocation and carbohydrates. Forest Ecology and Management 2011; 261(3): 695-702. http://dx.doi.org/10.1016/j.foreco.2010.11.028.

Radin B, Bergamaschi H, Reisser C Jr, Barni NA, Matzenauer R, Didoné IA. Eficiência de uso da radiação fotossinteticamente ativa pela cultura do tomateiro em diferentes ambientes. Pesquisa Agropecuária Brasileira 2003; 38(9): 1017-1023. http://dx.doi.org/10.1590/S0100204X2003000900001. 
Raes D, Steduto P, Hsiao TC, Fereres E. AquaCrop - The FAO crop model to simulate yield response to water: reference manual. Roma: FAO; 2009.

Resende SV, Crepaldi IC, Pelacani CR, Brito AL. Influência da luz e substrato na germinação e desenvolvimento inicial de duas espécies de Calliandra Benth: (Mimosoideae - Leguminosae) endêmicas da Chapada Diamantina, Bahia. Revista Árvore 2011; 35(1): 107-117. http://dx.doi. org/10.1590/S0100-67622011000100013.

Sanquetta CR, Behling A, Corte AP, Cadori GC, Costa S Jr, Macedo JHP. Eficiência de conversão da radiação fotossintética interceptada em Fitomassa de mudas de Eucalyptus dunii Maiden em função da densidade de plantas e do ambiente de cultivo. Scientia Forestalis 2014; 42(104): 573-580.

Sas Institute. Getting started with the SAS learning edition. Cary: SAS Institute Inc.; 2003.

Silva BMS, Lima JD, Dantas VAV, Moraes WS, Sabonaro DZ. Efeito da luz no crescimento de mudas de Hymenaea parvifolia Huber. Revista Árvore 2007; 31(6): 1019-1026. http://dx.doi.org/10.1590/S0100-67622007000600006.
Sinclair TR, Muchow RC. Radiation use efficiency. Advances in Agronomy 1999; 65: 215-265. http://dx.doi. org/10.1016/S0065-2113(08)60914-1.

Stape JL, Binkley D, Ryan MG. Production and carbon allocation in a clonal Eucalyptus plantation with water and nutrient manipulations. Forest Ecology and Management 2008; 255(3-4): 920-930. http://dx.doi.org/10.1016/j. foreco.2007.09.085.

Stewart DW, Costa C, Dwyer LM, Smith DL, Hamilton RI, Ma BL. Canopy structure, light interception and photosynthesis in maize. Agronomy Journal 2003; 95(6): 1465-1474. http://dx.doi.org/10.2134/agronj2003.1465.

Taiz L, Zeiger E. Plant physiology. Porto Alegre: Artmed; 2013.

Varlet-Grancher C, Gosse G, Chartier M, Sinoquet H, Bonhomme R, Allirand JM. Mise au point: rayonnement solaire absorbé ou intercepté par um couvert végétal. Agronomie 1989; 9(5): 419-439. http://dx.doi.org/10.1051/ agro:19890501. 